\title{
PRELIMINARY EVALUATION REPORT
}

\section{Laboratory of Radiation Blology \\ University of Washington \\ Seattle, Washington}

December I, 1959 WATENT CLEARANCE OBTAINED. RELEASE TO
THE PUBLIC IS APPROVED. PROCEDURES
MRECTEN RRE ON EILE IN THE RECEIVING SECTION. 


\section{DISCLAIMER}

This report was prepared as an account of work sponsored by an agency of the United States Government. Neither the United States Government nor any agency Thereof, nor any of their employees, makes any warranty, express or implied, or assumes any legal liability or responsibility for the accuracy, completeness, or usefulness of any information, apparatus, product, or process disclosed, or represents that its use would not infringe privately owned rights. Reference herein to any specific commercial product, process, or service by trade name, trademark, manufacturer, or otherwise does not necessarily constitute or imply its endorsement, recommendation, or favoring by the United States Government or any agency thereof. The views and opinions of authors expressed herein do not necessarily state or reflect those of the United States Government or any agency thereof. 


\section{DISCLAIMER}

Portions of this document may be illegible in electronic image products. Images are produced from the best available original document. 


\section{- CHARIOT PROJECT, PHASE II PRELIMINARY EVALUATION REPORT}

\section{Introduction}

The participation of the Laboratory of Radiation Biology in Phase II of the Chariot Project included the organization and coordination of the marine program, the radiological analyses of marine samples, the preparation of a l1st of the fishes and of the marine invertebrates of the eastern chukchi Sea and, the survey of salmon streams in the vicinity of the Chariot site. Also, the Laboratory was host for the coordination meeting for the Environmental Program on June 2 and 3 in seattle, and for the Committee on Environmental Studies on october 8 and 9 at Fern Lake.

The Laboratory's program for the Charlot Project does not appear as an 1tem in the chariot budget because funds were originally budgeted for work at the Pacific Proving Ground. The change in program with the approval of the Division of Blology and Medicine was made later. The cost of the program for FY 1960 is about $\$ 15,000$, which includes travel, supplies, and the salarles of speclalists, but not the salaries of the permanent staff members who have. worked on the Charlot program. follows.

A discussion of the results to date of our program

\section{Organization of Marine Program}

The objectives of the program were to evaluate the biological cost in the marline environment of the Charlot experiment and to determine water movement in the eastern Chukchi Sea. To obtain these objectlves staff from the Department of oceanography, Unlversity of Washington, and their research vessel, the Brown Bear, and staff from the North Pacific Fisheries Exploration and Gear Research Branch of the Bureau of Commerclal Fisherles and their research vessel, the John N. Cobb, were engaged. As knowledge of the oceanography and blology of the area was scant, there was little foundation upon which to bulld the research programs. For this reason the programs were more extensive than they might otherwise have been. 
The proposal for the oceanography, program was submltted by Dr. Richard H. Fleming, executive officer, Department of Oceanography. In addition to the study of water movements for the purpose of predicting the probable fate of radioactive materials introduced Into the Chukchi Sea, the other major phases of this program included temperature and salinity observations, submarine geology studies, tidal observations, investigation of lagoons and blological studies related to the qualitative and quantitative ecology of the plankton. The Department of Oceanography has prepared and submitted their own report and has operated under their own contract.

The marine biological fleld program, other than the plankton studies, was conducted aboard the John Cobb. Samples were collected by means of otter trawl, biological dredge, midwater trawl, gill net, trap and beach seine. From the list of organisms in the collections a biological inventory was prepared for the purpose of documenting the flora and fauna of the area prior to the Chariot experiment. In addition to supporting the AEC program, the work of the John Cobb provided the Fish and Wildlife Service with information from which the potential of the area for commerclal flshing could be evaluated. (Because of joint interest, the cost of the John CObb cruise was shared by the AEC and Fish. and Wildife Service.) The quantity of fish in the collections was surprisingly small, but the collection of invertebrates was extremely rich. Nelther bottom flsh nor shellfish were present in commercial quantities at the 74 stations where collections were made.

Reports of the John Cobb cruise have been prepared by Dayton L. Alverson, Chief, North Pacific Flsheries Exploration and Gear Research Branch.

The Brown Bear and the John Cobb worked in the eastern Chukchi sea between the Bering Stralts and Cape Lisburne during August. In this remote area the mutual assistance of the scientific groups and crews aboard the two vessels was important in the operational and sclentific phases of the field program.

Speclalists were employed for the purpose of 1dentifylng the fishes and marine invertebrates in the collections. Also, because of the Importance of salmon to the people of Alaska, a flsheries biologist experienced in Alaskan salmon stream surveys was hired although it was realized that salmon runs in the vicinlty of the Chariot Site are not large. The Alaska Department of F1sh and Game was invited to conduct the salmon stream surveys but did not accept the invitation. 


\section{Radiological Analysis of Samples}

The field program included the scanning of samples for the purpose of helping in the selection of samples for later laboratory analyses. For this job a shielded two-inch well type scintillation crystal with scaler (for gamma counting) was installed aboard the John Cobb. Of the samples counted, the blological samples rarely exceeded the background count but the count of mud samples, although low, was generally greater than background.

Laboratory analyses by more sensitive methods confirmed the results of the field measurements. The radioactivity was low, but in addition, the radioactivity that was present could be accounted for by naturally occurring radioisotopes. In other words, radioactivity from man-made isotopes, if present, is below the sensitivity of the equipment and therefore, there appears to be little or no contamination from fallout in the eastern chukchi Sea. The results to date of the measurements of gross beta radioactivity in the marine samples from near the Chariot site are given in Table 1. Other analyses yet to be made are not expected to change materially the results that already have been obtalned.

The radioactivity of the biological samples as determined by analyses for gamma emitters appears to be from $\mathrm{K}^{40}$, a naturally occurring radioisotope. Based upon our past experiences, $\mathrm{zn} 65$ is an isotope that we would expect to find especially in muscle tissue. However, the gamma peak for $\mathrm{zn}^{65}$ was not apparent when the samples were analyzed using a crystal for which the limit of detectablitity was about four counts per sample.

The results of analyses of mud samples for gamma emitters indicated that $\mathrm{Ra}^{226}$ and its decay products accounted for the radioactivity in the sample. Again, radioisotopes from fallout were not apparent.

Although a few more special analyses are yet to be done, it is believed that the results already obtained are a reliable estimate of the existing level of radioactivity in the eastern Chukchi sea and that additional radiological, studies during the summer of 1960 are not needed.

\section{Lists of Fishes}

The identification of the fishes has been the responsibility of Dr. Norman J. Wilimovsky, Chief, Marine Fisheries Investigations, Bureau of Commercial Fisheries, Juneau, Alaska. Because 
Table 1. Gross Beta Radioactivity of Marine Samples from the Chukchi Sea, August 1959.

\begin{tabular}{|c|c|c|c|c|c|c|}
\hline \multirow[b]{2}{*}{ Common name } & \multirow[b]{2}{*}{$\begin{array}{l}\text { Station } \\
\text { number }\end{array}$} & \multirow[b]{2}{*}{$\begin{array}{l}\text { Number of } \\
\text { specimens }\end{array}$} & \multicolumn{4}{|c|}{$\mu \mu \mathrm{c} / \mathrm{g}$ (wet) } \\
\hline & & & muscle & $\begin{array}{l}\text { viscera } \\
\text { or liver }\end{array}$ & $\begin{array}{l}\text { skeleton } \\
\text { or bone }\end{array}$ & gonad \\
\hline Flatfish & 18,22 & 2 & 3.13 & 3.25 & 2.77 & \\
\hline Arctic cod & 23 & 5 & 2.88 & 1.69 & 3.15 & \\
\hline Smelt & 18 & 5 & 4.13 & 3.55 & 2.62 & \\
\hline Saffron cod & 18 & 1 & 5.54 & 1.48 & 2.75 & \\
\hline Herring & & 5 & 5.55 & 3.62 & 3.17 & \\
\hline Sculpin & & 3. & 3.97 & 2.54 & & \\
\hline Shrimp & 18 & 10 & 3.14 & 3.51 & & \\
\hline Scallop & 24 & 5 & 4.06 & 8.31 & & - \\
\hline Bentnose clam & 22. & 7 & 3.77 & 4.11 & & \\
\hline Yoldia (clam) & 22 & 3 & 4.60 & 4.00 & & \\
\hline$\overline{\text { King crab }}$ & 18 & 1 & 2.91 & 3.91 & 0.0 & \\
\hline Tanner crab & 18 & 3 & 2.52 & 3.18 & 1.58 & \\
\hline Hermit crab & 18 & 2. & 2.35 & 6.15 & 4.84 & \\
\hline Chionectes (crab) & 18 & 2 & 3.62 & 6.55 & 2.12 & \\
\hline Sea urchin & 18 & 4 & & 20.39 & .755 & 1.48 \\
\hline Snail & 20,25 & 10 & 2.83 & 3.07 & & \\
\hline Basket star & 18 & 1 & & 4.25 & 1.37 & \\
\hline Barnacle & 18 & 2 & & 13.85 & & 2.45 \\
\hline
\end{tabular}


of his knowledge and interest in the fishes of the Chukchl Sea and of the relatively smali number and varieties of fish that are found there, the identification is nearly complete. A program for the collection of marine fishes during the summer of 1960 is not contemplated.

Dr. Wilimovsky prepared a report of his work on November 25, 1959. The remainder of the discussion in this section is quoted verbatum from his report.

Identification of all forms collected in the Chariot area has been substantially completed. One or two genera require additional systematic judgment, and the proper nomenclatorial designation for three others must be determined on the grounds of nomenclatural priority. The 52 taxa recognised are as follows:

\section{MARINE FORMS}

Clupea harengus pallasi oncorhynchus gorbuscha oncorhynchus keta Salvelinus alpinus. Salvelinus malma osmerus dentex Mallotus villosus Eleginus gracilis Boreogadus saida Atheresthes stomias Hippoglossoides robustus Limanda aspera Pleuronectes quadrituberculatus Liopsetta glacialis Platichthys stellatus Hexogrammos sp. Hemilepidotus sp. Icelus s. spatula Triglops pingeli Artediellus scaber beringianus Megalocottus platycephalus Myoxocephalus scorpius
Myoxocephalus axillaris

Myoxocephalus jaok

Myoxocephalus stelleri

Myoxocephalus quadricornis

Microcottus sellaris

Gymnocanthus tricuspis orientalis

Enophrys lucasi

Nautichthys pribilovius

Aspidophoroides olriki

Podothecus acipenserinus

Liparis herschelinus

Iiparis sp.

Ammodytes hexapterus

Stichaeus punctatus

Eumesogrammus praecisus

Lumpenus fabricil

Lumpenus medius

Lycodes palearis arcticus

Lycodes raridens

Lycodes sp.

Gymnelis viridis

\section{FRESH WATER FORMS}

Savlelinus malma

Salvelinus alpinus

Coregonus autumnalis

Coregonus sardinella

corgeonus lavaretus pidschian
Thymalius arcticus signifer Cottus cognatus Gasterosteus aculeatus Pungitius pungitius 
The species list, as might be expected, is dominated by far-northern types. However, the charlot collection is unique in that it contains at least a dozen forms which heretofore have not been known to occur north of Bering Straits. As parts of the Chukchi Sea were studied by Russian expeditions in 1932 and 1933, the presence of these forms may represent either a general warming of the area, or a temporal extension of the range of Bering Sea fishes, owing to local oceanographic phenomena.

The catch records of 7,000 plus fish captured during the field operations, give some evidence of order of abundance of the different species. Numerically, the ten dominant marine forms within the area of our exploration of the Chukchi Sea were:

Boreogadus saida Clupea harengus paliasi Gymnocanthus tricuspis Artedielius scaber Mallotus villosus
Hippoglossoides robustus. osmerus dentex Myoxocephalus scorpius Triglops pingeli Eleginus gracilis

By frequency of occurrence within the station pattern, the ten dominant marine forms are:

Boreogadus saida

Gymnocanthus tricuspis

Hippoglossoldes robustus

Myoxocephalus scorpius

Triglops pingeli
Podothecus acipenserinus

Lumpenus fabricii

Artediellus scaber

Osmerus dentex

Lycodes spp.

Preliminary analysis does not indicate any definite pattern of abundance within the marine area studied. However, several of the species show distinctive ecological trends, and their occurrence is presently being analyzed with reference to substrate, temperature, and depth range. Also, decided interspecific relations between species were evident. To analyze these relationships objectively, the data are being subjected to Cole's test of association. Because of the number of tabulations required, this material has been entered on punch cards and will be analyzed with the ald of an electronic computer. Upon completion of these analyses, a final formal report can be prepared. It is proposed that the pertinent results be combined with similar material treating the invertebrate study and description of previous efforts in the area so as to provide a unified report on the aquatic biota in the Chukchi sea area included within the bounds of the Chariot study. $\therefore$

Recommendations for future studies of the fish fauna in the Chariot area remain substantially as stated in my report dated September 24, 1959. 


\section{List of Marine Invertebrates}

The identification of the marine invertebrates is being supervised by Dr. Albert K. Sparks, Associate Professor, College of Fisheries, University of Washington. His assistants are Mr. Walter Pereyra and Mr. Ian Ellis. Dr. Dora P. Henry of the Department of oceanography has offered to 1dentify the barnacles.

The collection of marine invertebrates is the best collection of all time in the eastern Chukchl sea and is large both in respect to number of specimens and to number of species. Because of the size of the collection and the lack of prior information about the marine invertebrates of the Chukchi Sea, classification cannot be completed by June, 1960 as originally planned.

The specimens are first sorted as to phylum and station and although this sorting is not complete, the wide range in varlety of organisms is indicated by the fact that representatives of fourteen phyla already have been found. The phyla present are

as follows:

1. Portfera

2. Coelenterata

3. Platyhelminthes

4. Nemertinea

5. Priapulida

6. Annelida

7. Echiurida
8. Sipunculida

9. Arthropoda

10. Móliusca

11. Bryozoa (Ectoprocta)

12. Brachiopoda

13. Echinodermata

14. Chordata (Tunicata)

In some cases specific identifications are easily accomplished and in a few instances already have been made for specimens in the phylum Moliusca. In the classes Amphineura, Gastropoda and Pelecypoda, 30 genera and 29 species have been recognized.

Although the 1dentification of the invertebrates will continue into next year, further collections in the Chukchi Sea during the summer of 1960 are not planned or needed. After identification has been completed, a report of the number of invertebrates (and $\mathrm{flsh}$ ) by specles and station is to be prepared.

\section{Salmon Stream Surveys}

Mr. Howard D. Smlth of the Fisheries Research Institute, College of Fisheries, Unlversity of Washington, conducted surveys of the streams in the vicinity of Charlot Site for the purpose of evaluating the salmon resource. He was in the field between August 5 and 20 and later prepared a final report of his observa- 
tions which was included in the october 1 progress report of the Laboratory of Radiation Biology.

The following remarks are extracted from his report:

"The return of salmon to the Cape Thompson area in 1959 probably amounted to $6-7,000 \mathrm{flsh}$, chlefly, if not all pinks. It is not possible to relate this numerical return to that of other years but it appears likely that this was a "normal" year. Significant chum runs may well occur from time to time, however, and it is possible that in years of higher water than that observed in 1959, small numbers of salmon may enter a few of the smaller streams in the area.

It seems quite certain that salmon contribute very little to the economy of the region. The villagers of both Kivalina and Tigara are primarily hunters rather than fishermen, and though the meagre stocks of salmon are easily within reach, they appear virtually unexploited. On the basis of present knowledge, only two streams in the study area appear important. They are, the Kukpuk and Singoalik rivers which both produce pinks, and probably some chums occasionally, during the month of August. The possibility of salmon utilizing the streams of the area either before or after the 1959 survey period is slight. Thompson (1951) pointed out that as one proceeds northward along the Pacific coast the races of salmon concentrate their spawning periods into a progressively shorter period in order that they take advantage of the progressively shorter periods of environmental optima. It is, therefore, probable that in order to adapt within the stringent environmental limitations of the Arctic, the salmon must enter the streams, spawn, and die in a very short period and virtually together."

The study of salmon is the one part of the marine program that should be continued during the summer of 1960. The stocks of salmon observed in "1'959 are totally unrelated to the stocks of spawning salmon that will occur in the streams during 1960. 1959 observations cannot be extrapolated to 1960. Recommendations for the 1960 program are included in the report by Smith and the requirements for logistic support have been forwarded to the San Francisco Operations office.

In this report marine mammals have not been mentioned because the Laboratory has not participated in the organization or coordination of that part of the marine program. The Arctic Health Research Center ( $\mathrm{Dr}$. Rausch) has the responsibility for the program by virtue of their knowledge of, experience with, and interest in marine mammals. 